\title{
近接場光による自己組織的ナノ光加工技術
}

\author{
八 井崇 \\ 東京大学大学院工学系研究科電気系工学専攻およびナノフォトニクス研究センター \\ †113-8656 東京都文京区弥生 2-11-16 \\ (2009 年 7 月 30 日受理)
}

\section{An Optical Nanofabrication with Self-assemble Manner using Optical Near-field}

Takashi YATSUI

Department of Electrical Engineering and Information Systems, also with Nanophotonics Research Center, The University of Tokyo 2-11-16 Yayoi, Bunkyo-ku, Tokyo 113-8656

(Received July 30, 2009)

\begin{abstract}
This article reviews the recent development of optical nanofabrication with self-assemble manner based on the nonadiabatic chemical reaction. In the first part of this article, we propose a new polishing method that uses near-field etching based on a non-adiabatic process, with which we obtained ultra-flat silica surface that had a minimum roughness of $1.37 \AA$. We believe our technique can be applied not only to flat substrates but also to three-dimensional substrates that have convex or concave surfaces. In the second part, we demonstrate the selective photochemical etching of Si in a self-organized manner, which strongly depends on the distribution of the optical near-field. This dependence was described by the virtual exciton-phonon-polariton model. The photoluminescence (PL) spectra from the etched $\mathrm{Si}$ exhibited a blueshifted PL peak at $1.8 \mathrm{eV}$, corresponding to Si nanocrystals of $2.8 \mathrm{~nm}$ diameter. Since, both method are based on the photochemical reaction they are compatible with mass-production and can be applicable to other materials.
\end{abstract}

KEYWORDS : dressed photon, nonadiabatic process, self-assembly, size and position control

\section{1.ま え がき}

近接場光を用いた微細加工方法の原理確認として，プ ローブを用いて近接場光を発生させ，そのプローブを走 査することで任意形状の物質を堆積する手法が行われて いる。この手法により，加工寸法を光の回折限界以下の 微小寸法精度で実現可能となった（量的変革）だけでな く ${ }^{1)}$, 近接場光の持つ寸法依存共鳴現象の発見など質的 変革が達成された ${ }^{2)} 。 こ の$ 結果, 従来いわゆる一筆書き 加工であった微細加工の分野において, 一括大面積加工 の可能性をもたらした ${ }^{3)}$ 。本節では近接場光の特徵のう ち, 非断熱光化学反応 ${ }^{4}$ の特長を積極的に活かした一括 加工技術について紹介する。

E-mail : yatsui@ee.t.u-tokyo.ac.jp

\section{2. 原理：非断熱光化学反応}

本節ではナノフォトニクス特有な反応である非断熱光 化学反応について概説する。まず, ナノ寸法物質に光を 照射したときに発生した分極が，周囲に大きな機械的ひ ずみを誘起し, その結果, コヒーレントフォノンを局所 的に生成する場合がある (Fig. 1 (a) ) ${ }^{4)}$ 。これは熱源と はならず，励起子ポラリトンとフォノンとの混合状態で ある励起子フォノンポラリトン，言い換えるとナノ寸法 物質間の近接場光相互作用を媒介する仮想励起子フォノ ンポラリトン（ドレスト光子）を形成する。すなわち, ナノ寸法物質の励起子ポラリトンのエネルギーとフォノ ンのエネルギーが, 近接するナノ寸法物質に移動可能と なる。

このエネルギー移動を使うと, 入射光の光子エネルギ 一が近接するナノ寸法物質中の電子を励起準位に励起さ 


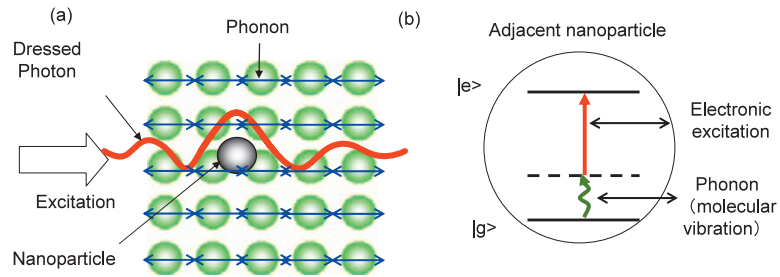

Fig. 1. (color online). (a) Schematic of the generation of the dressed photon. (b) Nonadiabatic excitation.

せるほど高くなくとも（すなわち断熱過程による光化学 反応が起こらなくとも), フォノンのエネルギー移動に より近接物質中の分子振動が誘起され, 分子振動エネル ギー準位を介した多段階励起により電子が励起される (非断熱励起過程, Fig. 1（b))。したがって, 従来の加 工で使われる紫外光などの短波長光源が不要となる。さ らには，ドレスト光子が励起されるナノ物質の周りのみ で反応が励起されるため, 従来の伝播光加工において必 要であった近接場光発生用のためファイバプローブやマ スクが不必要となり, 高効率に一括加工を実現すること が可能となる。

\section{3. 非断熱光化学反応によるオングストローム 平坦化 ${ }^{5}$}

近年の光産業は目覚しい発展を遂げており,この発展 を支えるレーザ機器において, 高出力化, 短波長化, 短 パルス化への要望が強まっている。このような産業界の 要請に答えるためには，レーザ機器を構成するレンズや ミラー等の光学素子の高性能化を達成する必要がある。 光学素子の高性能化にとって現在一番の問題となるのが 表面粗さ（以下 $R_{a}$ 值）の低減である。これは，表面粗 さが大きいと，

(1)光学素子表面での散乱損失が大きくなる

(2)レーザ損傷閾值が上げられない

などの問題が生じるためである。ここで， $R_{a}$ 值は平均 線（面）からの絶対值偏差の平均值として下記の式 (1) で表される (Fig. 2)。

$$
\begin{aligned}
R_{a} & =\frac{1}{l} \int_{0}^{l}|\mathrm{f}(\mathrm{x})| \mathrm{dx} \\
& \cong \frac{1}{n} \sum_{i=1}^{n}\left|f\left(x_{i}\right)\right|
\end{aligned}
$$

$(l:$ 測定長さ, $d x:$ AFM 測定時の面内分解能に対応, $|f(x)|$ : 平均線からの表面高さの絶対値, $n$ : 評価時の測 定点数)

しかしながら, 市販されている光学素子の $R_{a}$ 值は 2〜 $5 \AA$ 程度であり，近年，下げ止まりを余儀なくされ ている。その原因のひとつは, 光学素子の製造方法にあ

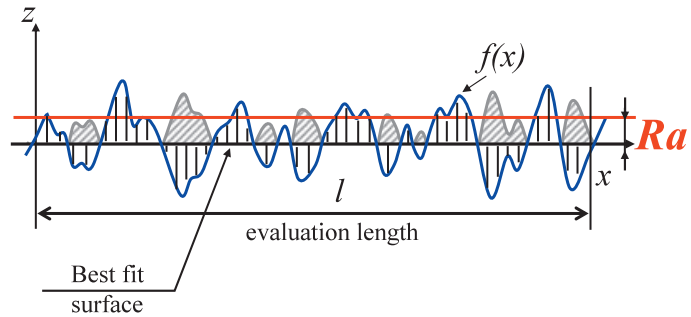

Fig. 2. (color online). The definition of $R_{a}$.

る。現在, 光学素子は機械化学方式と呼ばれる方法によ り製作されており，その手法は，研磨パットの間に，被 研磨材料であるガラスを挟み, 研磨剤（酸化セリウム 等）を流しながら擦る。この方法では, 研磨パットの平 坦性や研磨剤の粒径などの制限から， $R_{a}$ 值は $2 \AA$ 程度 が限界になっている。さらに，細かい領域での凹凸だけ でなく, 大面積に渡る溝（スクラッチ）や数十 $\mathrm{nm}$ の穴 （ディグ）が発生する。以上の現状より，光学素子の高 性能化（ $R_{a}$ 值低減）のためには，全く新しい手法によ る研磨方法が必要となっている。上記の問題を解決する ために, 従来の化学機械的手法ではなく, 近接場光エッ チングを使うことにより, 次世代レーザ用光学素子向け の平坦化基板を実現する技術について説明する。

紫外領域を中心に，ミラー基板として最も需要の大き い合成石英を用いて，近接場光エッチングの詳細を紹介 しよう。合成石英をエッチングする気体としては塩素ラ ジカル $\left(\mathrm{Cl}^{*}\right.$ : 塩素分子が分解されたもの) がある。合 成石英とは反応しない不活性な塩素分子（光吸収端波長 $400 \mathrm{~nm}^{6}$ ) 雲囲気中に基板を導入し，レーザ光（波長 $532 \mathrm{~nm}$ ）を照射する（Fig. 3（a））。この光の波長は光吸 収端波長より長いので，塩素分子に吸収されず基板とは 反応しない。一方，この光により，基板表面の局所的な 凹凸部に近接場光が発生すると非断熱光化学過程 ${ }^{5,7,8)}$ に より塩素分子は分解し, 塩素ラジカルが発生する (Fig. 3(a))。その結果, この塩素ラジカルが合成石英表面と 反応し，凹凸構造のみがエッチングされ基板が平坦化さ れる（Fig. 3 (b)）。そして，最終的に基板に凹凸部がな くなると近接場光は発生しなくなるため, 反応が自動的 に停止し余計なエッチングを防ぐことが可能となる (Fig. 3 (c))。

$R_{a}$ 值の評価方法には，原子間力顕微鏡（AFM）を用 いる。従来, $R_{a}$ 值の観測には, 白色干涉計が用いられ ているが, 横分解能が波長程度と大きく, また $R_{a}$ 值の 測定限界能が $5 \mathrm{~A}$ 程度であるため, 横分解能が $10 \mathrm{~nm}$ 程 度で，凹凸の分解能が $0.1 \mathrm{~A}$ 程度である AFM を使用す る。AFM では走査範囲が $10 \mu \mathrm{m}$ と狭いため, 測定領域 による誤差が大きくなる。そこで，平行平面基板の中心 

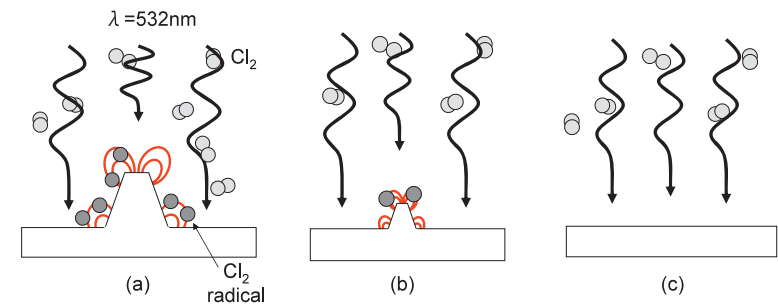

Fig. 3. (color online). Schematic of the near-field etching.
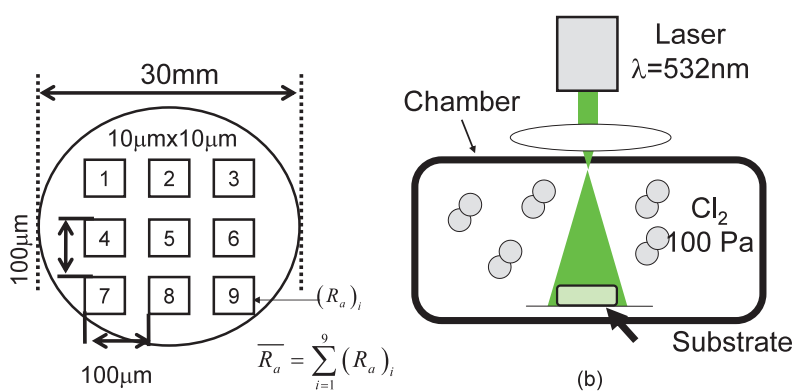

(a)

Fig. 4. (color online). Schematic of (a) the scanning and (b) experimental set-up.

付近 9 点を $100 \mu \mathrm{m}$ ピッチで AFM により測定を行い (Fig.4 (a))，各エリアで算出される表面粗さ $\left(R_{a}\right)_{i}$ の 值を得る。その值を平均した

$$
\overline{R_{a}}=\sum_{i=1}^{9}\left(R_{a}\right)_{i}
$$

によってその基板の表面粗さ $R_{a}$ 值を決定する。基板エ ッチングのためのガスには塩素を選択し, 塩素導入後の チャンバーの压力を $100 \mathrm{~Pa}$ とする。照射光源について

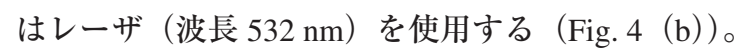

Fig. 4 は近接場光エッチング前後の AFM 像の比較を 示している。この比較像より表面の凹凸が低減すること が明らかである。さらに, Fig.5 (a) に示されるよう に，近接場光エッチング前には多く見られたスクラッチ (白楕円の内側) がなくなっていることがわかる。この AFM 図の変化をより詳細に比較するために, 白破線を 通る断面図を Fig. 5 (c) に示す。この図からピークーバ レー值が近接場光エッチングによって $1.2 \mathrm{~nm}$ から 0.5 $\mathrm{nm}$ に減少していることがわかる。

最後に $R_{a}$ 值の平均值のエッチング時間依存性を Fig. 6 (a) に示す。この結果より, 基板への光照射時間に応 じて単調に表面粗さ $R_{a}$ 值が減少する結果となっている。 光照射時間 120 分では, $R_{a}$ 值は $1.4 \mathrm{~A}$ まで減少する。こ の值は 9 点での平均であり, その中で得られた $R_{a}$ 值と して, 最小 $1.1 \mathrm{~A}$ である。また, 各照射時間における $R_{a}$ 值の分散 (Fig. 6 (b) ) も光を照射することで減少する
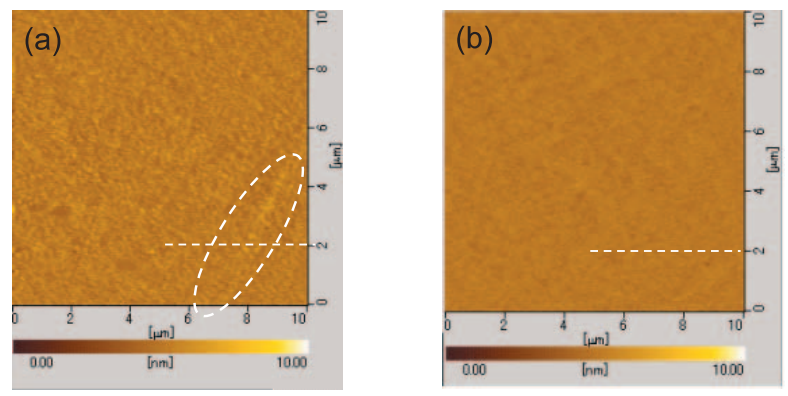

(c)

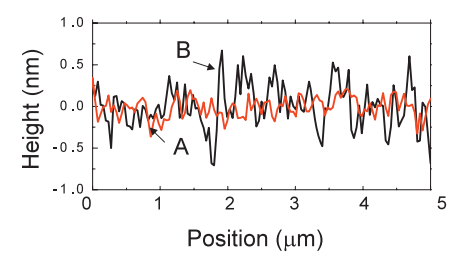

Fig. 5. (color online). Typical AFM images of the silica substrate (a) before and (b) after nonadiabatic optical near-field etching. (c) Cross-sectional profiles along the white dashed lines in (a) and (b). Curve A and B correspond to the profile after and before etching, respectively.
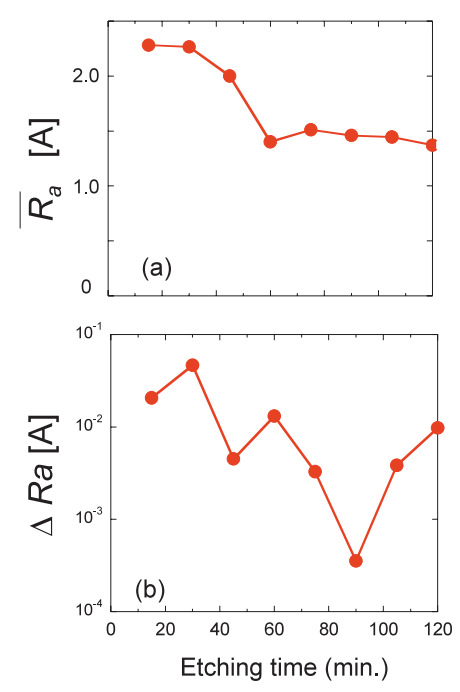

Fig. 6. (color online). The etching time dependence of (a) the average $R_{a}\left(\overline{R_{a}}\right)$ and (b) the standard deviation of $R_{a}\left(\Delta R_{a}\right)$.

\section{ことがわかる ${ }^{6)}$}

本手法は光化学反応を利用したものであるため, 平坦 基板のみならずレンズやミラーなどの曲率を有する基板 や, 中空レンズの内壁の平坦化など, 従来の研磨技術で は全く不可能な加工法への応用にも展開が期待される。

\section{4. 非断熱光化学反応による寸法・位置制御加 工 $^{9)}$}

数ナノメートルの量子ドットによって構成されるナノ 
フォトニックデバイス ${ }^{10,11)}$ を実現させるためには，量子 ドットの寸法を $\mathrm{nm}$ 以下の精度で制御し, さらにはその 堆積位置を同じく $\mathrm{nm}$ 以下の精度で堆積させる必要があ る。

上記目的を達成するために, 非断熱光化学反応と, 半 導体の量子サイズ効果を用いた，位置・寸法制御方法に ついて詳細を紹介しよう。シリコンを光化学エッチング によって加工すると, シリコンの寸法はエッチングとと もに減少する。その寸法の減少にともなって, シリコン の吸収端エネルギーは量子サイズ効果によって増大す る。そして，シリコンの大きさが小さくなり，その吸収 端エネルギーが, 光化学エッチングに用いる光子エネル ギーよりも，大きくなると光が吸収されなくなるので, 光化学エッチングはストップする。つまり, 照射する光 のエネルギーによって作製する量子ドットの寸法が制御 可能となる ${ }^{12)}$ 。

量子ドットの形成位置を制御するために，近接場光発 生源としてピラミッド構造を作製した（Fig.7 (a) ) ${ }^{13)}$ 。 光化学エッチングは $\mathrm{HF}(50 \%): \mathrm{H}_{2} \mathrm{O}_{2}(30 \%)=1: 1$ 溶 液を用い, 光照射には光子エネルギー $1.8 \mathrm{eV}(26 \mathrm{~mW} /$ $\mathrm{cm}^{2}$, 照射スポット $\left.500 \mu \mathrm{m}\right)$ を使用した。上記の条件に より，以下のように光化学エッチングが進行する ${ }^{14)}$ 。

（1）レーザ照射によりシリコン中に電子・正孔対が 生成される（Fig. 7 (b))。

（2）生成された正孔と水によりシリコンが酸化され, この部分が HF によって溶出する。

( 3 ) $\mathrm{H}_{2} \mathrm{O}_{2}$ により基板から電子が抜き出され, $\mathrm{H}_{2} \mathrm{O}_{2}$
と $\mathrm{H}^{+}$が反応して水となる（Fig. 7 (c) )。

(4) 残ったシリコンが棒状に繋がったナノ結晶を形 成する (Fig. 7 (d))。

近接場光強度は, 基板形状に対する偏光方向によって 大きく変化するため, 波長板を通して光化学エッチング の実験を行った。

Fig. 7 （e）および 7（f）に示すように，3 分間光を照 射することで, 照射位置の表面が黒く変化した。この表 面の変化の原因を知るために, 室温において光励起によ る発光（Photoluminescence : PL）を測定した（Fig. 8, 励起光子エネルギー $3.81 \mathrm{eV})$ 。その結果, 発光のピーク エネルギーが $1.8 \mathrm{eV}$ であり，シリコンナノ結晶の大き さとして直径 $2.8 \mathrm{~nm}$ に対応することがわかった。また, このピークエネルギーが光化学エッチングに用いた照射 エネルギーと対応することから，作製された量子ドット

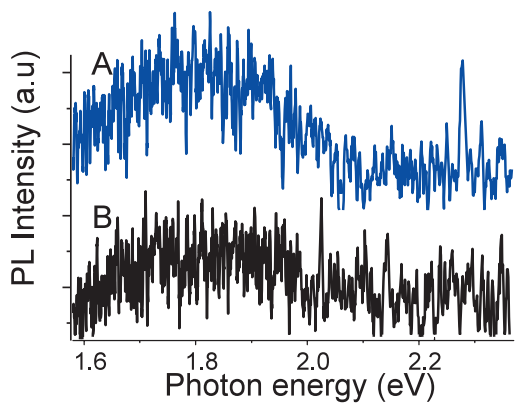

Fig. 8. (color online). Room temperature PL spectra of the photo-chemically etched $\mathrm{Si}$ illuminated for $3 \mathrm{~min}$ (curve A) and $10 \mathrm{~s}$ (curve B).

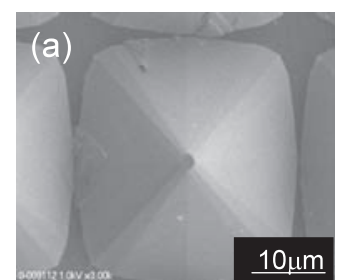

(b)

(c)

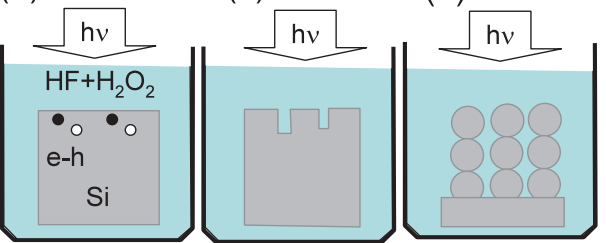

Inside the

$I \rightarrow$ illuminated spot
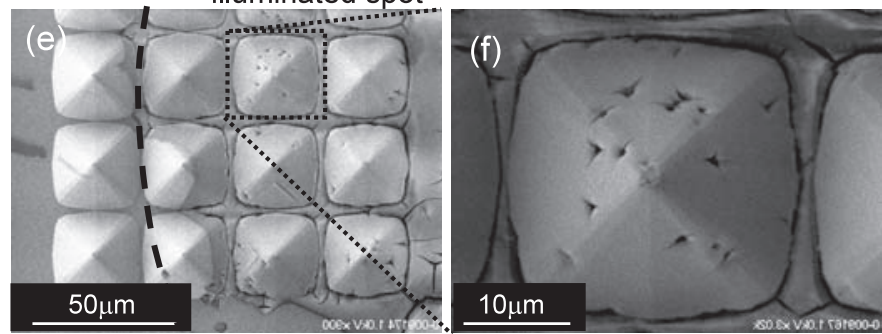

Fig. 7. (color online). (a) SEM image of pyramidal Si. (b) -(d) A schematic of the formation of bridging Si nanocrystals. (e) and (f) SEM images of pyramidal $\mathrm{Si}$ after dipping in the etching solution for $3 \mathrm{~min}$ with illumination. 
の寸法が光のエネルギーによって制御可能であることが 示された。

次に, 照射光の偏光依存性の結果を示す。Fig.9 (a) および 9 (b) はそれぞれ, $\mathrm{x}$ 軸に対して 45 度偏光 $\left(P_{45}\right)$, および $\mathrm{x}$ 軸に対して平行偏光 $\left(P_{0}\right)$ によるエッ チング後 (10 秒照射) の結果である。黒い楕円破線が 示すように $P_{45}$ では, 偏光に沿った二つのエッジが黒く 変化し, $P_{0}$ では 4 つの全てのエッジが黒く変色したこ とがわかる。Fig. 9（b）の結果に対応して, 近接場光学 顕微鏡による発光分布を測定した結果が, Fig.9 (c) (形状像) および 9 (d) (1.8 eV における発光像) であ る。Fig.9（b）と9（d）の対応関係から, 局所的に黒 く変化した場所のみ, 光化学エッチングされたことが示 され，偏光による加工位置制御が可能であることがわか る。

上記の偏光依存性の原因を説明するために, 光強度分 布 $(I(r))$ および, 強度分布に強度勾配をかけた值 $(I N F=I(r) \times d I(r) / d r)$ の計算結果をそれぞれ, Fig. 10 (a) $\left(P_{45}\right)$ および $10(\mathrm{~b})\left(P_{0}\right)$, Fig. $11(\mathrm{a})\left(P_{45}\right)$ およ び $11 （ \mathrm{~b})\left(P_{0}\right)$ に示す（光子エネルギー $\left.1.8 \mathrm{eV}\right)$ ここ で,

$$
\begin{aligned}
& d I(r) / d r \\
= & \sqrt{\{\partial I(x, y, z) / \partial x\}^{2}+\{\partial I(x, y, z) / \partial y\}^{2}+\{\partial I(x, y, z) / \partial z\}^{2}}
\end{aligned}
$$

である。いずれの結果もシリコンピラミッドの頂点から シリコン側に $250 \mathrm{~nm}$ 下がった位置での分布を示してい

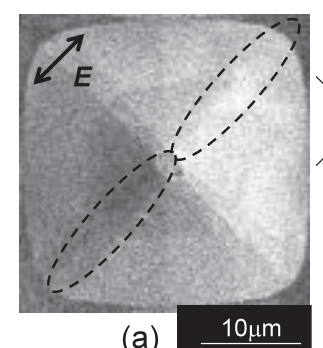

(a)

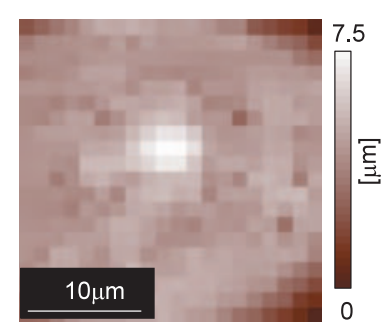

(c)
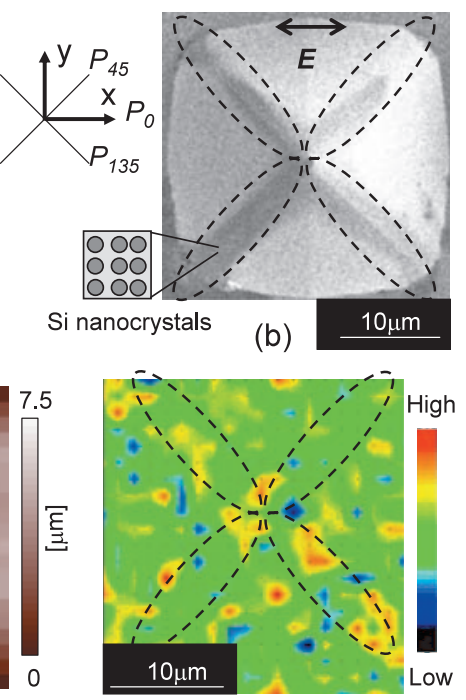

(d)
Fig. 9. (color online). SEM images after $10 \mathrm{~s}$ photochemical etching with polarization (a) $P_{45}$ and (b) $P_{0}$. (c) Topographical image of the pyramidal Si. (d) Spatial distribution of near-field PL intensity at $1.8 \mathrm{eV}$.
る（Fig. 10（c））。この（3）式で示される強度勾配に 光強度をかけた值 INF は, 仮想励起子フォノンポラリ トン（Virtual exciton-phonon-polariton : EPP）の分布と一 致しており，この強度の大きい場所において非断熱光化 学反応が促進される ${ }^{7,8,15)}$ 。先ず, $I(r)$ の分布から, 偏光 方向に対して, 構造のエッジ部（角 B・D（Fig. 10（a)）
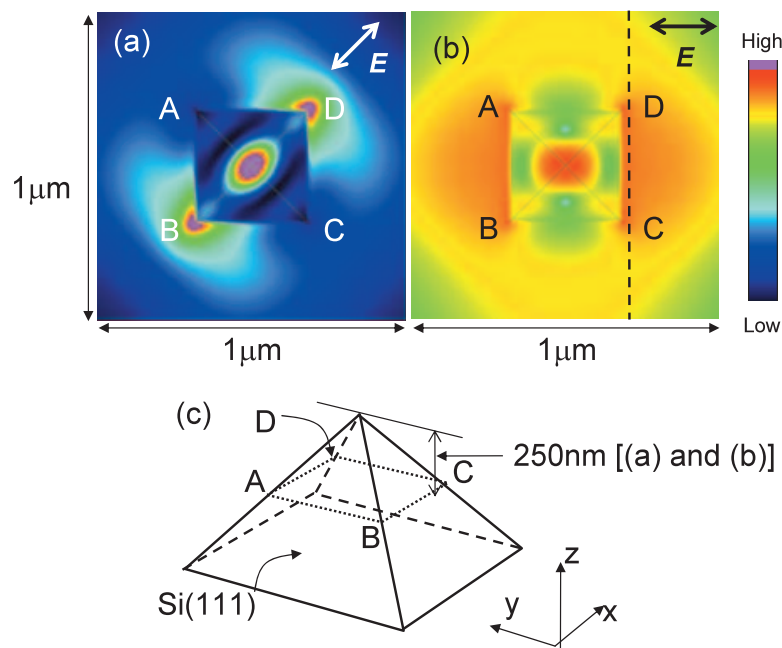

Fig. 10. (color online). The spatial distribution of the electrical field intensity, $I(r), 250 \mathrm{~nm}$ below from the Si tip with polarization (a) $P_{45}$ and (b) $P_{0}$, respectively. (c) Schematic of the pyramidal Si.
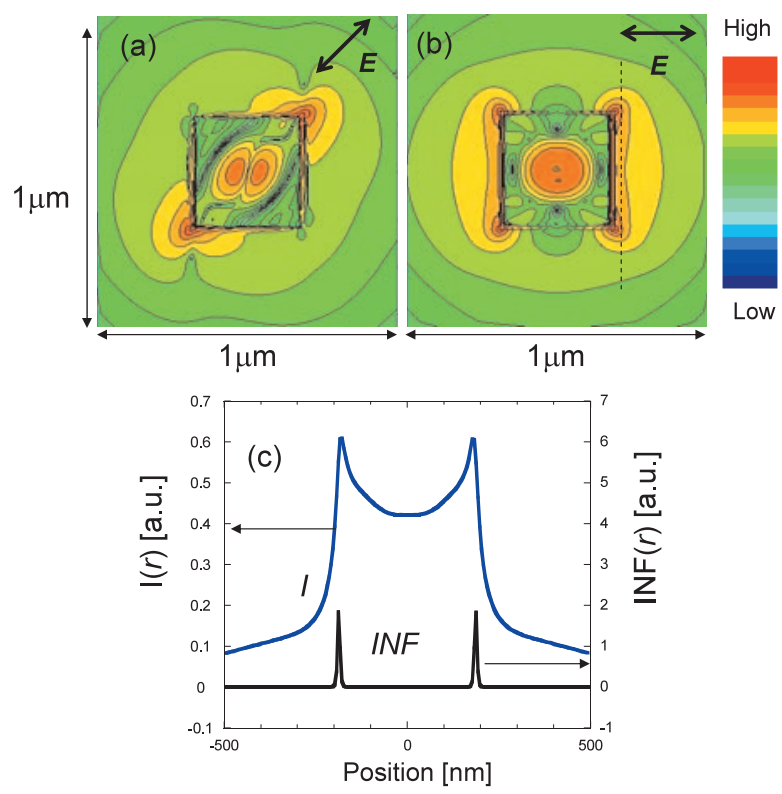

Fig. 11. (color online). The spatial distribution of $I(r) \times d I$ $(r) / d r$ at the 250-nm below the $\mathrm{Si}$ tip with polarization (a) $P_{45}$ and (b) $P_{0}$, respectively. (c) Cross sectional profiles along the dashed lines in Fig. 9 (b) (curve $I$ ) and Fig. 10 (b) (curve $I N F$ ). $I N F(r)=I(r) \times d I(r) / d r$. 
および辺 $\mathrm{AB} \cdot \mathrm{CD}$ （Fig. 10（b））での増大が見られる が，この分布と実験結果（Fig.9（a）扔よび 9 (b)）が 一致していないことがわかる。これに対して，INF $(r)$ の 分布から, $P_{0}$ 偏光の場合において, 辺ではなく 4 つの 角 $(\mathrm{A}, \mathrm{B} ， \mathrm{C}$ および $\mathrm{D})$ において局在して強度が強く なっていることがわかる（Fig. $11 （ \mathrm{~b})$ および11（c)）。 つまり，シリコンピラミッドの 4 つの角において EPP が強く励起され，この EPPによる非断熱光化学反応に よってシリコンの光化学エッチングが促進されたことを 示している。

\section{5. む す び}

本稿ではナノフォトニクスに扔いてのみ観測可能な現 象と，それを用いてナノ寸法の精度を持ち一括可能な近 接場光加工について解説した。いずれの手法も光化学反 応を利用したものであるため，ここで示した合成石英， シリコン以外の材料（金属，アモルファス材料，他の半 導体材料）などの加工にも応用可能である。さらに，形 状に起因して局在する近接場光の性質を用いることは, これまでナノ寸法加工に必要とされていたプローブやマ スクが不要となるため, 多品種多量生産が求められる将 来の社会的要求に答えられる革新的な技術である。

\section{謝辞}

本稿で紹介させていただいたオングストローム平坦化 の研究についてデー夕をご提供下さった多幡能德，平田 和也（シグマ光機株式会社）の各氏に媣く感謝致しま す。

\section{文献}

1) T. Yatsui, T. Kawazoe, M. Ueda, Y. Yamamoto, M. Kourogi and M. Ohtsu : Appl. Phys. Lett. 81, 3651 (2002).

2) T. Yatsui, S. Takubo, J. Lim, W. Nomura, M. Kourogi and M. Ohtsu : Appl. Phys. Lett. 83, 1716 (2003).

3) T. Yatsui, W. Nomura and M. Ohtsu : Nano Lett. 5, 2548 (2005).

4) T. Kawazoe, K. Kobayashi, S. Takubo and M. Ohtsu : J. Chem. Phys. 122, 024715 (2005).

5) T. Yatsui, K. Hirata, W. Nomura, Y. Tabata and M. Ohtsu : Appl. Phys. B : Lasers and Optics 93, 55 (2008).

6) R. Kullmer and D. Büerle : Appl. Phys. A 43, 227 (1987).

7) T. Kawazoe, M. Ohtsu, Y. Inao and R. Kuroda : J. Nanophotonics 1, 011595 (2007).

8) H. Yonemitsu, T. Kawazoe, K. Kobayashi and M. Ohtsu : J. Luminescence 122/123, 230 (2007).

9) T. Yatsui and M. Ohtsu : Appl. Phys. Lett. 95, 043104 (2009).

10) T. Yatsui, S. Sangu, T. Kawazoe, S.J. An, J. Yoo and G.-C. Yi : Appl. Phys. Lett. 90, 223110 (2007).

11) T. Yatsui, S. Sangu, K. Kobayashi, T. Kawazoe, M. Ohtsu, J. Yoo and G.-C. Yi : Appl. Phys. Lett. 94, 083113 (2009).

12) H. Koyama and N. Koshida : J. Appl. Phys. 74, 6365 (1993).

13) T. Yatsui, M. Kourogi, K. Tsutsui, J. Takahashi and M. Ohtsu : Opt. Lett. 25, 1279 (2000).

14) A.G. Cullis and L.T. Canham: Nature 353, 335 (1991).

15) K. Kobayashi, S. Sangu, H. Ito and M. Ohtsu : Phys. Rev. A. 63, 013806 (2001). 